\title{
ВИКОРИСТАННЯ ПРОБЛЕМНОГО ПІДХОДУ ПРИ ВИКЛАДАННІ МЕДИЧНОЇ І БІОЛОГІЧНОЇ ФІЗИКИ
}

\section{O. Z. Ivanchenko, O. Z. Melnikova \\ Zaporizhzhia State Medical University \\ THE USE OF PROBLEM APPROACH IN TEACHING OF MEDICAL AND BIOLOGICAL PHYSICS}

\begin{abstract}
Мета дослідження - обгрунтування необхідності застосування технології проблемного навчання у вищих закладах освіти для підвищення ефективності підготовки сучасних фахівців.

Матеріали та методи дослідження. Проведено аналіз типової, робочої програм з “Медичної і біологічної фізики” і навчальнометодичного забезпечення, яке застосовується на кафедрі медичної фізики, біофізики і вищої математики, з метою виявлення питань, вивчення яких доцільно проводити за технологією проблемного навчання. Методом спостереження встановлювався рівень активності студентів. За допомогою аналізу виконаних ними контрольних зрізів знань з’ясовували ступінь досягнення конкретних навчальних цілей.

Результати й обговорення. У статті наведено приклади використання проблемних завдань при вивченні таких складних питань, як механізми виникнення мембранного потенціалу спокою і потенціалу дії, утворення електричного поля в тілі людини при розповсюдженні хвилі збудження у серці та інших органах, особливості транспорту речовин у біомебранах різних клітин. Показано, що вирішення проблемних завдань на заняттях з медичної і біологічної фізики має відбуватись 3 метою інтеграції 3 дисциплінами навчальної програми підготовки лікарів, зокрема з фізіологією людини та інших навчальних курсів, у яких використовуються знання про фізичні і фізико-хімічні основи процесів життєдіяльності людини, про дію на її організм фізичних факторів навколишнього середовища і принципи їх використання в медичних діагностичних і терапевтичних приладах.

Висновки. Перевагами застосування проблемного навчання при вивченні медичної і біологічної фізики є активізація розумової діяльності студентів і підвищення їхньої внутрішньої мотивації. Умовами успішного використання технології служать глибокі професійні знання та педагогічна майстерність викладача і високий рівень підготовки студентів.
\end{abstract}

Ключові слова: проблемна ситуація; медична і біологічна фізика.

The aim of the study - to prove the need of problem-based learning for improvement of modern professionals training.

Materials and Methods. The analysis of typical and working program "Medical and Biological Physics" and educational-methodical materials was made for identifying issues, which are appropriate to the problem-based learning. The method of observation was applied for determining of students activity level. The degree to achieve specific educational goals was assessed by analyzing of the students' knowledge control sections.

Results and Discussion. The article gives examples of problematic tasks in the study of mechanisms of resting and action potentials, occurrence of the electric field in the body due to the spread of excitation wave in the heart and in the other organs, the features of the substances transport through the plasmatic membranes of the different cells. It is shown that the solution of tasks on a practical trainings by medical and biological physics should take the aim to integrate with physiology and other courses that use knowledge about the physical and physicochemical foundations of human life, the effects on the body of physics environmental factors and principles of their use in medical devices.

Conclusions. The advantages of the use of problem-based learning of medical and biological physics are activation of mental activity of students and increasing of their intrinsic motivation. Terms of the successful use of technology are profound professional knowledge and pedagogical skills of the teacher and a high level of students training.

Key words: problematic situation; medical and biological physics.

Вступ. На даному етапі розвитку людства головним завданням вищої школи є формування творчої і гармонійної особистості, яка вміє логічно мислити, знаходити рішення в проблемних ситуаціях. Знання дуже швидко оновлюються, тому сьогодні недо-

(C) О. 3. Іванченко, О. 3. Мельнікова статньо засвоїти їх певну суму. Навчання у вищому закладі освіти повинно стимулювати активну розумову діяльність студентів, а для цього їм необхідно вміти добувати, систематизувати, накопичувати знання, аналізувати власний досвід, узагальнювати інформацію і робити висновки [8]. Впровадження в 
навчальний процес проблемно-пошукових методів сприяє формуванню здатності студентів до творчого вирішення проблем, допомагає вихованню таких вмінь, як самостійно побачити і сформулювати проблему, висунути гіпотезу і запропонувати засоби її перевірки, зібрати дані, перевірити й обробити їх, сформулювати висновки і припустити можливість практичного застосування одержаних результатів.

Розробка технології проблемного навчання досить складна і потребує від викладача високої педагогічної майстерності, а також і багато часу для підготовки. Проблемні ситуації, які пропонує викладач на лекціях, практичних заняттях, мають бути дуже ретельно продумані. Студенти, зіткнувшись із проблемою, повинні розмежовувати відоме і невідоме, чітко знати, що саме їм треба пізнати, а також вміти намічати шляхи вирішення протиріч. Існують певні правила організації проблемно-пошукових занять [2-7]. Проблемна ситуація повинна викликати пізнавальне напруження, але ж не бути занадто складною. При використанні проблемно-пошукового навчання необхідне органічне поєднання розвитку творчих здібностей студентів 3 реалізацією освітніх задач, тобто набуттям учнями нових знань, вмінь і навичок. Інтерес і зацікавленість студентів у вирішенні нестандартних, незвичайних та несподіваних задач, викликаючи позитивні емоції, сприяє успішній і якісній організації проблемного навчання [1, 3, 10].

Мета дослідження - обгрунтування необхідності застосування технології проблемного навчання у вищих закладах освіти для підвищення ефективності підготовки сучасних фахівців.

Матеріали та методи дослідження. Для встановлення питань, при вивченні яких доцільно використовувати проблемний підхід, проаналізовано типову, робочу програми, навчальні посібники, якими користуються студенти першого курсу медичного факультету на заняттях з медичної і біологічної фізики. Методом спостереження встановлювався рівень активності студентів. За допомогою аналізу виконаних ними контрольних зрізів знань 3'ясовували ступінь досягнення конкретних навчальних цілей.

Результати й обговорення. На заняттях з медичної і біологічної фізики викладачі кафедри використовують проблемний підхід до вивчення більшості тем курсу. Постановка проблеми може бути початковим етапом у процесі засвоєння знань, а пошук її вирішення забезпечує успішні умови набуття нових вмінь, навичок. Окрім того, проблемно-пошукове заняття може слугувати як засіб контролю рівня результатів навчання. Для створення проблемної ситуації ми використовуємо різні прийоми і засоби. Наприклад, студентам пропонується інформація, яка містить у собі суперечність.

На занятті “Мембранний потенціал спокою” вивчається одна з важливіших властивостей мембрани - здатність створювати і підтримувати постійну різницю потенціалів між внутрішньоклітинним вмістом і позаклітинною рідиною, тобто мембранний потенціал спокою. Наявність МПС є основою збудливості клітин, що обумовлює регуляцію внутрішньоклітинних процесів, функціонування нервової системи, здійснення і регуляцію м’язового скорочення. Проблемний підхід на даному занятті можна застосувати для пояснення іонних механізмів потенціалу спокою в мембранах збудливих клітин. Студенти добре знають, що концентрація основних потенціалутворюючих іонів у клітині і поза нею така: всередині багато катіонів калію і органічних аніонів, а зовні переважають катіони натрію і аніони хлору. Логічно припустити, що при такому розподілі іонів буде відбуватися полегшена дифузія всіх названих іонів, адже на попередньому занятті “Транспорт речовин у біологічних мембранах” студенти вивчали механізми, умови, транспортні системи електродифузії. В даному випадку рух іонів по градієнту концентрації привів би до вирівнювання концентрацій основних іонів і тоді не виникала би різниця потенціалів всередині й зовні клітини. Для вирішення протиріччя, яке виникає при даному припущенні, студенти мають порівняти проникність мембрани для основних потенціалутворюючих іонів у спокої, ознайомитись більш детальніше з будовою калієвих і натрієвих каналів, а також з умовою їх роботи і функціонування, а ще 3'ясувати роль натрій-калієвого насосу в створенні необхідного градієнта концентрації основних іонів. Після обговорення всіх можливих факторів впливу на рух іонів через мембрану студенти чітко виділяють іонні причини мембранного потенціалу спокою. Для підтвердження своїх висновків учням необхідно також ознайомитись і вміти використовувати математичні моделі описання мембранного потенціалу спокою, а саме з рівняннями Нернста і Гольдмана - Ходжкіна.

Ще одним прикладом застосування проблемного підходу є вивчення теми “Основи електрокардіографії”. Відомо, що електрокардіограма (ЕКГ) відображує розповсюдження хвилі збудження в серці. Проте під час вивчення попередньої теми процес 
збудження нервових, м'язових клітин вже відомий студентам як потенціал дії (ПД). Тому існує можливість поставити проблему походження складної форми ЕКГ, у якій поверхневими електродами реєструють електричне поле, потенціал якого змінюється, відображуючи різні фази ПД сукупності кардіоміоцитів, що послідовно збуджуються відповідно до перебігу серцевого циклу.

3'ясувати одне з важливих питань з області гемодинаміки про те, як змінюється лінійна швидкість течії крові в різних відділах кровоносної системи, можливо шляхом вирішення проблеми. На попередньому занятті студенти вивчали основні закони гідродинаміки, а саме закон Пуазейля, рівняння неперервності та інші. Протиріччя виникає тоді, коли студентам пропонується графік зміни лінійної швидкості течії крові в різних відділах кровоносної системи (рис. 1). В аорті, яка має більший поперечний переріз, спостерігається найбільша лінійна швидкість течії крові, і навпаки, в капілярах, судинах з найменшим діаметром, швидкість течії крові мінімальна.

Для вирішення даного протиріччя студенти повинні проаналізувати рівняння неперервності і його використання для біологічних систем, а саме для описання течії крові по кровоносній системі. В ході обговорення даного питання студенти доходять висновку про те, що при визначенні лінійної швидкості течії крові враховується сумарна площа перерізу всіх судин, які входять до певного відділу кровоносної системи. Капіляри - судини, які

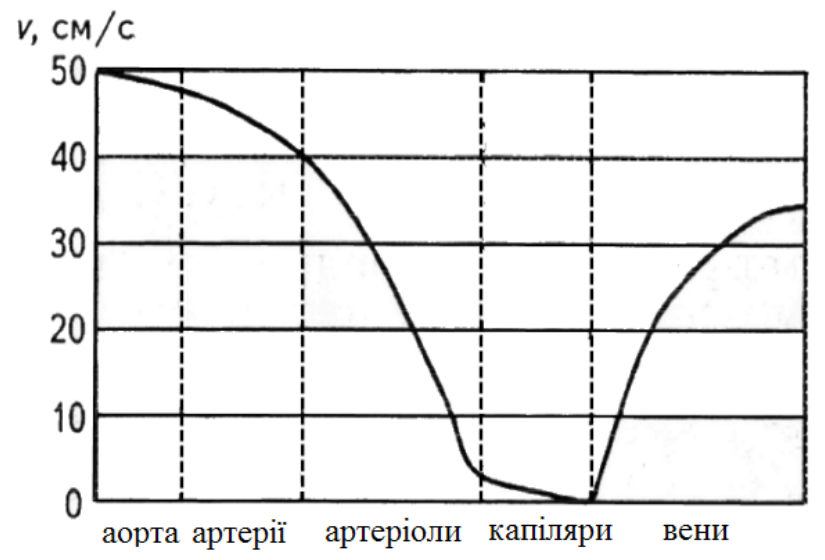

Рис. 1. Графік зміни лінійної швидкості течії крові в різних відділах кровоносної системи.

мають найменший діаметр, але їх кількість значно перевищує кількість судин будь-якого іншого відділу кровоносної системи. Тому лінійна швидкість течії крові в капілярах найменша і це має певний фізіологічний сенс. Використовуючи рівняння неперервності, студенти пояснюють зміни лінійної швидкості кровотечі у різних відділах кровоносної системи (різкий спад в артеріолах, а також підйом у венах).

Проблемна ситуація може виникати також у результаті ознайомлення із різними тлумаченнями одного й того самого явища, факту. Прикладом цього може бути з'ясування механізмів переносу глюкози через мембрани різних клітин шляхом пасивного (А) й активного (Б) транспорту (рис. 2).

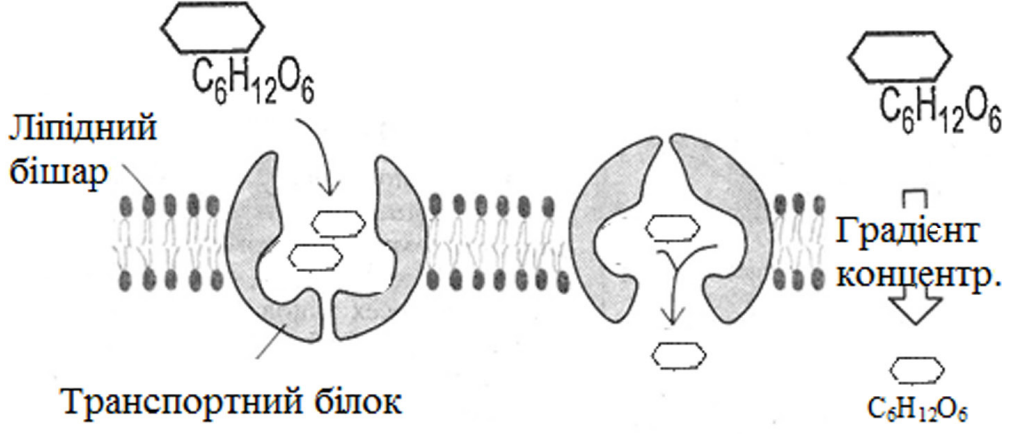

A

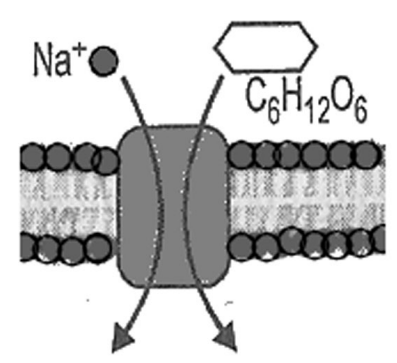

Б

Рис. 2. Перенос глюкози пасивним (А) й активним (Б) транспортом.

Висновки. Використання дидактичної системи проблемного навчання у вищому навчальному закладі - “це творча, емоційно насичена праця викладачів і студентів, яка потребує цілеспрямованості, великих вольових зусиль, високої відповідальності. Воно забезпечує міцне засвоєння знань, робить на- вчальну діяльність захоплюючою, оскільки вчить мислити, долати труднощі” [9]. Починаючи заняття зі створення проблемної ситуації, викладач формує у студентів мотивацію на навчання, що є дієвим фактором активного залучення особистості в процес пізнання. Він полягає в тому, що студент сам 
шукає та одержує нову інформацію, коли аналізує, порівнює, конкретизує, синтезує, узагальнює фактичний матеріал.

Проте на пошук вирішення деяких проблем потрібно багато часу. Цей факт відносять до одних 3 недоліків проблемного навчання в порівнянні 3 традиційним [4]. Окрім того, використання цієї навчальної технології потребує високого педагогічного вміння від викладача і певної підготовки

\section{Список літератури}

1. Басова Н. В. Педагогика и практическая психология / Н. В. Басова. - Ростов н/Д : Феникс, 2000.- 416 с.

2. Вітвицька С. С. Основи педагогіки вищої школи [Електронний ресурс] / С. С. Вітвицька. - К., 2003. 271 с. - Режим доступу : http://nashaucheba.ru/v12486/.

3. Галузинський В. М. Основи педагогіки та психології вищої школи в Україні : навч. посіб. для викладачів та аспірантів вузів / В. М. Галузинський, М. Б. Євтух ; ІСДО, Київський лінгвістичний ун-т. - К. : ІНТЕЛ, 1995. - 168 с.

4. Герелес Л. М. Проблемное обучение в вузе / Л. М. Герелес // Молодой ученый. - 2011. - № 4, т. 2. С. $78-80$.

5. Дроздова І. П. Методика викладання, педагогіка та психологія вищої освіти : навч. посіб. / І. П. Дроздова. - Х. : ХНАМГ, 2008. - 140 с.

\section{References}

1. Basova, N.V. (2000). Pedagogika i prakticheskaia psykhologiia [Pedagogy and Practical Psychology]. Rostov na Donu: Feniks [in Russian].

2. Vitvytska, S.S. (2003). Osnovy pedahohiky vyshchoi shkoly [Basics of pedagogics in higher school]. Kyiv. Retrieved from http://nashaucheba.ru/v12486/ [in Ukrainian].

3. Haluzinskyi, V.M., \& Yevtukh, M.B. (1995). Osnovy pedahohiky ta psykholohii vyshchoi shkoly v Ukraini [Basics of pedagogics in higher school of Ukraine]. Kyiv: ÍNTEL [in Ukrainian].

4. Hereles, L.M. (2011). Problemnoe obuchenie v vuze [Problem-based learning in high school]. Molodoi uchenyi - Young Scientist, 4, (2), 78-80 [in Russian].

5. Drozdova, I.P. (2008). Metodyka vykladannia, pedahohika ta psykholohiia vyshchoi osvity [Methods of teaching, pedagogy and psychology]. Kharkiv: KhNAMH [in Ukrainian].
[4, 6]. Однак, виходячи з тих переваг проблемнопошукових методів у навчанні, їх використання в сучасній освіті просто необхідне.

Перспективи подальших досліджень. 3 урахуванням доцільності, підготовки студентів і викладачів впроваджувати проблемно-пошуковий підхід для вивчення якомога більших тем курсу медичної і біологічної фізики.

6. Манько В. А. Проблемне навчання як актуальна науково-педагогічна проблема / В. А. Манько // Засоби навчальної та науково-дослідної роботи. - Х., 2006. Вип. 25. - С. 102-106.

7. Наволокова Н. П. Енциклопедія педагогічних технологій та інновацій / автор-укладач Н. П. Наволокова. - Х. : Вид. група “Основа”, 2009. - 176 с.

8. Огнев’юк В. О. Освіта в системі цінностей сталого людського розвитку / В. О. Огнев’юк. - К. : Знання України, 2003. - 450 с.

9. Сайт Національного педагогічного університету ім. М. П. Драгоманова. - Режим доступу : http://npu.edu.ua.

10. Ягупов В. В. Педагогіка : навч. посіб. / В. В. Ягупов. - К. : Либідь, 2002. - 560 с.

6. Manko, V.A. (2006). Problemne navchannia yak aktualna naukovo-pedahohichna problema [Problem learning as relevant scientific and pedagogical problem]. Zasoby navchalnoi ta naukovo-doslidnoi roboty. - Means of Educational and Research Work, 25, 102-106 [in Ukrainian].

7. Navolokova, N.P. (2009). Entsyklopedia pedahohichnykh tekhnolohii ta innovatsii [Encyclopedia of educational technology and innovation]. Kharkiv: Osnova [in Ukrainian].

8. Ohneviuk, V.O. (2003). Osvita v systemi tsinnostei staloho liudskoho rozvytku [Education in the value system of sustainable human development]. Kyiv: Znannia Ukrainy [in Ukrainian].

9. Sait Natsionalnoho pedahohichnoho universytetu im. M.P. Drahomanova [Site of M.P. Drahomanov National Pedagogical University]. http://npu.edu.ua. Retrieved from http://npu.edu.ua

10. Yahupov, V.V. (2002). Pedahohika [Pedagogy]. Kyiv: Lybid [in Ukrainian]. 